
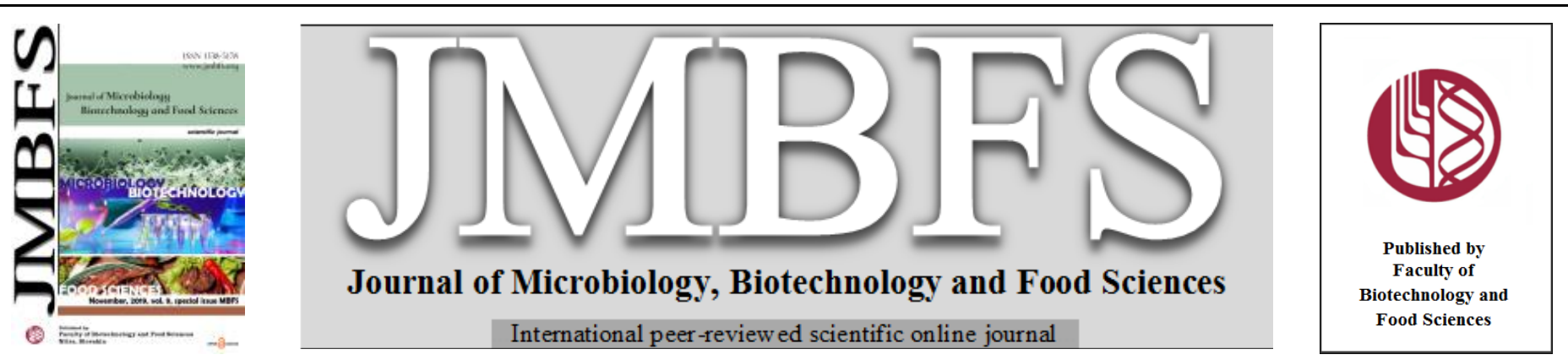

\title{
ANTIMICROBIAL AND ANTIOXIDANT PROPERTIES OF ESSENTIAL OILS AGAINST BACTERIAL STRAINS ISOLATED FROM HUMAN SEMEN
}

\author{
Simona Kunová ${ }^{1}$ Eva Tvrdá ${ }^{2}$ Eva Ivanišová ${ }^{3}$, Miroslav Ondrejovič4, Daniela Chmelová ${ }^{4}$, Margarita Terentjeva ${ }^{5}$, Miroslava \\ Kačániová ${ }^{6,7}$
}

Address(es):

${ }^{1}$ Slovak University of Agriculture, Faculty of Biotechnology and Food Sciences, Department of Food Safety and Hygiene, Trieda Andreja Hlinku 2, 94976 Nitra, Slovakia, phone number: +421376415807.

${ }^{2}$ Slovak University of Agriculture, Faculty of Biotechnology and Food Science, Department of Animal Physiology, Tr. A. Hlinku 2, 94976 Nitra, Slovakia.

${ }^{3}$ Slovak University of Agriculture, Faculty of Biotechnology and Food Sciences, Department of Technology and Quality of Plant Products, Tr. A. Hlinku 2, SK-94976 Nitra, Slovakia.

${ }^{4}$ University of Ss. Cyril and Methodius Faculty of Natural Sciences, Department of Biotechnology,, Nám. J. Herdu 2, Trnava, 917 01, Slovakia.

${ }_{5}^{5}$ Latvia University of Life Sciences and Technologies, Institute of Food and Environmental Hygiene, Faculty of Veterinary Medicine, Latvia K. Helmaņa iela 8, LV3004, Jelgava, Latvia.

${ }^{6}$ Slovak University of Agriculture in Nitra, Faculty of Horticulture and Landscape Engineering, Department of Fruit Sciences, Viticulture and Enology, , Trieda Andreja Hlinku 2, 94976 Nitra, Slovakia, phone number: +421 376414985.

${ }^{7}$ University of Rzeszow, Faculty of Biology and Agriculture, Department of Bioenergy and Food Technology, Zelwerowicza St. 4, PL-35601 Rzeszow, Poland.

*Corresponding author: miroslava.kacaniova@gmail.com

doi: 10.15414/jmbfs.2019.9.special.409-413

\section{ARTICLE INFO}

Received 30. 6. 2019

Revised 23.9. 2019

Accepted 7. 10. 2019

Published 8. 11. 2019

Regular article OPEN $\partial_{\text {ACCESS }}$

\begin{abstract}
The aim of our study was to work the antimicrobial and antioxidant activities of Citrus paradisi peel, Citrus reticulata peel, Juniperus communis fruit, Eucalyptus globulus leaf, and Cananga odorata flower essential oils. Essential oil samples were analysed by GC chromatography coupled with FID detector (Agilent $6890 \mathrm{~N}$ ). The plant essential oils were tested regarding their antioxidant activity and antimicrobial activity against 13 species of Gram positive $\left(\mathrm{G}^{+}\right)$and Gram negative $\left(\mathrm{G}^{-}\right)$bacteria isolated from human semen and identified by MALDI-TOF MS Biotyper. Isolated $\mathrm{G}^{+}$and $\mathrm{G}^{-}$were tested for antibiotics resistance Among tested bacteria, the lowest antibiotic susceptibility for Corynebacterium species were observed for ciprofloxacin in three cases, for gentamycin in three cases, for vancomycin in two cases and for tetracycline in five cases. Antioxidant activities tested using DPPH method reveals that Cannaga odorata had the higher antioxidant activity and the lowest was found at J. communis essential oil. Antimicrobial activities showed that all the essential oils inhibited on the entire 13 species of Gram positive $\left(\mathrm{G}^{+}\right)$and Gram negative $\left(\mathrm{G}^{-}\right)$bacteria being used. However, $C$. odorata have the best antimicrobial effect against Corynebacteria. Good antimicrobial activity of $C$. paradise was found against Corynebacteria also. Strong antibacterial activity of $C$. odorata against E. coli, E. faecium, P. aglomerans, P. fulva and S. agalactiae were found.
\end{abstract}

Keywords: biological activity, Gram positive bacteria, Gram negative bacteria, plants, semen samples

\section{INTRODUCTION}

Recent studies have shown that the simple presence of bacteria in semen samples may compromise the sperm quality. The bacteria responsible for semen contaminations generally originate from the urinary tract of patients or can be transmitted by the partner via sexual intercourse (Purvis and Christiansen, 1993). The most frequently isolated microorganism in male patients with genital tract infections or semen contamination is Escherichia coli. The negative influence of this species on sperm quality is partially due to its effect on motility (Diemer et al., 2003). The influence of gram-positive uropathogenic bacteria on sperm morphology and function has been poorly investigated until now. Aerobic cocci are present in about $50 \%$ of semen samples of male partners in infertile couples. Enterococcus faecalis was isolated from $53 \%$ of patients, micrococci from $20 \%$ and alpha-haemolytic streptococci from $16 \%$ of the infected samples. Increased prevalence of genital tract infections caused by E. faecalis is associated with compromised semen quality in terms of sperm concentration and morphology. The presence of micrococci and alpha-haemolytic streptococci does not appear to exert any detrimental effect on sperm quality (Qiang et al., 2007). Corynebacterium species, which are recognized as members of the normal human flora, were isolated from the skin, mucous membranes, and gastrointestinal tract. Corynebacterium species have occurred predominantly among patients with prosthetic and other medical devices. Currently, 88 valid studies have been published on Corynebacterium species, and further definition of the pathogenic role of these species in human infections and of the mechanisms of pathogenesis continues to be elucidated (Long et al., 2018).

Escherichia coli are Gram-negative bacteria that are found in food and the environment. Most E. coli are harmless, but some cause diseases such as diarrhoea and respiratory pneumonia (Kalita et al., 2014). Most people infected with the Shiga toxin-producing $E$. coli have stomach cramps, diarrhoea (usually bloody), vomiting and high fever, and more serious haemolytic uremic syndrome (HUS). Escherichia coli is one of the world's best-characterized organisms, because it has been extensively studied for over a century. Typically, a commensal bacterium, $E$. coli resides in the lower intestines of a slew of animals. Outside of the lower intestine, E. coli can adapt and survive in a very different set of environmental conditions. Biofilm formation allows $E$. coli to survive, and even thrive, in environments that do not support the growth of planktonic populations. E. coli can form biofilms virtually everywhere: in the bladder during a urinary tract infection, on in-dwelling medical devices, and outside of the host on plants and in the soil. Streptococcus is one of the major pathogens causing mastitis in dairy cows, mainly $S$. agalactiae, $S$. dysgalactiae, and $S$. uberis. The proportion of cow mastitis caused by Streptococcus is as high as $30 \%$. Notably, Streptococcus is prevalent in many countries (Coffey et al., 2006). In adults, S. agalactiae may cause meningitis or septicaemia as well as localized infections such as subcutaneous abscesses, urinary tract infection or arthritis. The drivers behind emergence of $S$. agalactiae disease in adults are poorly understood (Delannoy et al., 2013). 
Essential oils and plant products have had a tremendous application in food, cosmetic and folk medicine, and are continuously investigated for their antimicrobial activities. Essential oils (EOs) obtained from plants are a complex mixture of some compounds such as hydro-carbons, alcohols, esters, aldehydes and have been reported to exhibit inhibitory activities against a wide spectrum food spoilage microorganism (Uysal et at., 2011). Citrus is one of the most consumed fruits in the world and contain a high amount of useful by-products which include essential oil. Grapefruit (Citrus paradisi) belongs to the Citrus genus, a taxa of flowering plants in the family Rutaceae. The peel of Citrus fruits is a rich source of flavanones and many polymethoxylated flavones, which are very rare in other plants. These compounds, not only play an important physiological and ecological role, but are also of commercial interest because of their multitude of applications in the food and pharmaceutical industries (Ahmad et al., 2006). The berries of Juniperus communis contain $0.2-3.42 \%$ of volatile oil, depending on specific parameters of cultivation such as the climate, the soil, the altitude, and the degree of ripeness. Traditionally the oil is collected by extraction using organic solvent: methanol, n-hexane, but the main used process is steam distillation of the crushed, dried, partially dried, or fermented berries (Carpenter et al., 2012).

Essential oils are the odorous, volatile products of the secondary metabolism of an aromatic plant, which are often concentrated in a particular organ of the plant such as leaves, stems, bark or fruit and are stored in secretory cells, cavities, canals, epidermic cells or glandular trichomes. Approximately 3000 essential oils are known, 300 of which are commercially important especially for the pharmaceutical, agronomic, food, sanitary, cosmetic and perfume industries. A number of studies have demonstrated the antimicrobial properties of Eucalyptus essential oils against a wide range of microorganisms. These studies, however, are focused on a few Eucalyptus species, especially Eucalyptus globulus oil, which has been shown to have a wide spectrum of antimicrobial activity (Tyagi and Malik, 2011).

Cananga (Cananga odorata) is known for its fragrant flowers. In addition, cananga is also known as a medicinal plant, the leaves as a remedy for itch, dried flowers as malaria drugs, fresh flowers for aroma therapy, as well as the bark as a remedy for ulceration. Essential oil contained in cananga flowers is used as a fragrance ingredient. Cananga oil has quite a high economic value in the world market. In addition to economic value, cananga trees also have ecological value, where this trees can be used for slope stability due to the type of roots are strong (Mahfud et al., 2017).

The main aim of our study were evaluate the chemical composition, antimicrobia and antioxidant activity of five essential oils against Gram positive and Gram negative bacteria isolated from human semen. In our study we also identified bacterial strain with mass spectrometry and tested these strains for antibiotic resistance.

\section{MATERIAL AND METHODS}

\section{Essential oils}

Citrus paradisi peel oil, Citrus reticulata peel oil, Juniperus communis fruit oil, Eucalyptus globulus leaf oil, and Cananga odorata flower oil, were purchased from Aromatika (Russia). Samples were obtained via steam distillation as pure essential oils. The essential oil samples were stored in glass vials with teflonsealed caps at laboratory temperature in darkness.

\section{Microorganisms}

Thirteen different kinds of Gram positive $\left(\mathrm{G}^{+}\right)$and Gram negative $\left(\mathrm{G}^{-}\right)$bacteria were isolated from human ejaculates. The semen samples were obtained from 30 healthy donors by masturbation into sterile container. Only ejaculates showing normal semen parameters were used. The samples underwent liquefaction at 37 ${ }^{\circ} \mathrm{C}$ for $30 \mathrm{~min}$. Experiments were performed within $1 \mathrm{~h}$ from sample collection. Semen samples were inoculated on Tryptone Soya agar (TSA) and Levine agar (LA). After incubation, bacteria were selected for further confirmation with MALDI-TOF MS Biotyper. Isolated $\mathrm{G}^{+}$and $\mathrm{G}^{-}$species were tested for antibiotics resistance against ciprofloxacin, gentamycin, vancomycin, tetracycline, tigecycline and imipenem, ampicillin and chloramphenicol $10 \mathrm{msg}$. Three G bacteria (Escherichia coli, Pantotea aglomerans, $P$. fulva) and ten $\mathrm{G}^{+}$bacteria (Corynebacterium autimocus, four strains of $C$. glucuromoliticum, C. singulaere and two strains of Streptococcus agalactiae) were tested. The bacteria species were maintained in Mueller Hinton Agar (Merck, Germany). The mother cultures of each bacteria tested were set up $24 \mathrm{~h}$ before the assays in order to reach the stationary phase of growth. The tests were assessed by inoculating Petri dishes from the mother cultures with proper sterile media. The main aim was to obtain the microorganism concentration of $10^{5}$ colony forming units (cfu). $\mathrm{mL}^{-1}$.

\section{Antibiotic susceptibility testing}

The antibiotic susceptibility test was performed by using Disc Diffusion Method. Four different forms of sensitivity discs with $10 \mathrm{mcg}$ concentrations were used for studying the in vitro sensitivity of isolates: ciprofloxacin, gentamycin, vancomycin, tetracycline, tigecycline and imipenem, ampicillin and chloramphenicol. These discs were obtained from "Oxoid". The results were interpreted according to EUCAST (2019).

\section{Antimicrobial activity}

\section{Disc diffusion method}

We used the agar disc diffusion method for the determination of antimicrobial activities of the essential oil. Briefly, a suspension of the tested microorganism $\left(0.1 \mathrm{~mL}\right.$ of $10^{5}$ cells per $\left.\mathrm{ml}\right)$ was spread on the solid media plates. Filter paper discs $(6 \mathrm{~mm}$ in diameter) were impregnated with $15 \mu 1$ of the oil and placed on the inoculated plates. They were inoculated onto the surface of Mueller Hinton Agar (MHA, Oxoid, Basingstoke, United Kingdom). These plates, after remaining at $4{ }^{\circ} \mathrm{C}$ for 2 hours, were incubated anaerobically at $37^{\circ} \mathrm{C}$ for $24 \mathrm{~h}$. The diameters of the inhibition zones were measured in millimeters. All the tests were performed in duplicate.

\section{Radical scavenging activity - DPPH method}

Radical scavenging activity of essential oils was measured using 2,2-diphenyl-1picrylhydrazyl (DPPH) according to Sanchéz-Moreno et al., (1998) with slight modification. The sample $(0.1 \mathrm{ml})$ was mixed with $3.9 \mathrm{ml}$ of DPPH solution (0.025 g DPPH in $100 \mathrm{ml}$ methanol). Absorbance of the reaction mixture was determined using the spectrophotometer Jenway (6405 UV/Vis, England) at 515 $\mathrm{nm}$. The scavenging activity percentage (AA\%) was determined according formula:

$\mathrm{AA} \%=\left[\left(A_{0}-A_{A T}\right) / A_{0} \times 100\right]$

where $\mathrm{A}_{0}$ is absorbance of control reaction (DPPH radical); $\mathrm{A}_{1}$ is the absorbance in presence of sample

\section{Gas chromatography}

Essential oil samples were analysed by Agilent $6890 \mathrm{~N}$ chromatograph (Agilent Technologies, Santa Clara, California, USA) with FID detector. System control and data analysis were processed using the Agilent ChemStation software Rev. B.04.03-SP1 (Agilent Technologies). The chromatographic separation was performed in the DB- 23 column $(0.25 \mathrm{~mm}$ i.d., $30 \mathrm{~m}$ long, $0.25 \mu \mathrm{m}$ film thickness) (Agilent Technologies), and $5 \mu 1$ of the sample was injected. The injector temperature was $250^{\circ} \mathrm{C}$, and the FID temperature was set at $250{ }^{\circ} \mathrm{C}$. The carrier gas (nitrogen) flow was $1.1 \mathrm{ml} / \mathrm{min}$ (constant flow) with a split ratio 1:100 and a temperature program from $40^{\circ} \mathrm{C}$ to $80^{\circ} \mathrm{C}$ at $3{ }^{\circ} \mathrm{C} \cdot \mathrm{min}^{-1}$, from $80^{\circ} \mathrm{C}$ to 180 ${ }^{\circ} \mathrm{C}$ at $5{ }^{\circ} \mathrm{C} \cdot \mathrm{min}^{-1}$, and from $180{ }^{\circ} \mathrm{C}$ to $220{ }^{\circ} \mathrm{C}$ at $8{ }^{\circ} \mathrm{C} \cdot \mathrm{min}^{-1}$ and finally held at $220^{\circ} \mathrm{C}$ for $15 \mathrm{~min}$

\section{Statistical analyses}

All measurements and analyses were carried out in triplicate. Experimental data were evaluated by basic statistical variability indicators using the Microsoft ${ }^{\mathrm{TM}}$ Excel ${ }^{\circledR}$ program. Dependency rate between the tested traits was expressed using the linear correlation analysis.

\section{RESULTS AND DISCUSSION}

Some previous studies have identified bacteria in semen as being a potential factor in male infertility (Anitha et al., 2006; Weng et al., 2014). Similar results were obtained in our study (Table 1). Kiessling et al. (2008) performed PCR amplification of bacterial rDNA on 34 semen samples, and identified grampositive anaerobic cocci, Corynebacterium spp., Staphylococcus, Lactobacillus, Streptococcus spp., Pseudomonas spp., Haemophilus and Acinetobacter spp. as the largest groups in different specimens. Corynebacterium is an emerging multidrug-resistant bacteria (Hahn et al., 2016). In our study Corynebacterium species were resistant for ciprofloxacin on three case, for gentamycin on three case, for vancomycin on two case and for tetracycline on five case. 
Table 1 Antibiotic resistance of bacterial strains isolated from human semen

\begin{tabular}{lccccccccc}
\hline Microorganisms & CIP & GEN & VAN & TET & TGC & IMP & AMP & CHL \\
\hline Corynebacterium autimocus & S & S & S & R & - & - & - & - \\
\hline Corynebacterium glucuromoliticum & S & S & R & R & - & - & - & - \\
\hline Corynebacterium glucuromoliticum & S & R & R & R & - & - & - & - \\
\hline Corynebacterium glucuromoliticum & $\mathrm{S}$ & $\mathrm{R}$ & $\mathrm{S}$ & $\mathrm{S}$ & - & - & - & - \\
\hline Corynebacterium glucuromoliticum & $\mathrm{S}$ & $\mathrm{R}$ & $\mathrm{S}$ & $\mathrm{R}$ & - & - & - & - \\
\hline Corynebacterium singulare & $\mathrm{R}$ & $\mathrm{S}$ & $\mathrm{S}$ & $\mathrm{R}$ & - & - & - & - \\
\hline Enterococcus faecalis & $\mathrm{R}$ & - & - & - & $\mathrm{S}$ & $\mathrm{R}$ & $\mathrm{S}$ & - \\
\hline Enterococcus faecalis & $\mathrm{S}$ & - & - & - & $\mathrm{S}$ & $\mathrm{S}$ & $\mathrm{S}$ & - \\
\hline Escherichia coli & $\mathrm{R}$ & $\mathrm{S}$ & - & $\mathrm{S}$ & - & $\mathrm{R}$ & - & - \\
\hline Pantotea aglomerans & $\mathrm{S}$ & $\mathrm{S}$ & - & $\mathrm{S}$ & - & $\mathrm{S}$ & - & - \\
\hline Pantotea fulva & $\mathrm{S}$ & $\mathrm{S}$ & - & $\mathrm{S}$ & - & $\mathrm{S}$ & - & - \\
\hline Streptococcus agalactiae & - & - & $\mathrm{S}$ & $\mathrm{R}$ & $\mathrm{S}$ & - & - & $\mathrm{R}$ \\
\hline Streptococcus agalactiae & - & - & $\mathrm{S}$ & $\mathrm{R}$ & $\mathrm{S}$ & - & - & $\mathrm{S}$ \\
\hline
\end{tabular}

Legend: CIP-ciprofloxacin; GEN-gentamycin; VAN-vancomycin; TET-tetracycline; TGC-tigecycline; IMPimipenem; AMP-ampicillin; CHL-chloramphenicol

In table 2 we can observe the antimicrobial activity of five essential oils against bacteria isolated from human sperm. Our results show that the best antibacterial activity against Corynebacterium species for Cananga odorata essential oil were found on $C$. autimocus, $C$. glucoromoliticu and $C$. singulare. The study of antibacterial properties proved the sensitivity of all wild strains tested to EO: $E$. coli; Bacillus sp.; Pseudomonas sp.; K. oxytoca; Corynebacterium sp.; Nocardia sp.; S. aureus; Enterobacter sp.; E. agglomerans and Streptococcus group D. It showed, however, some differences in sensitivity profile, and Gram-positive species are more sensitive to the EO, which is very likely to be explained by the lower structural complexity of their cell walls. Traditional antibiotics act on a single cell site, and thus can develop bacterial resistance, there is then the EO as an alternative to the use of conventional antibiotics. The results open perspectives for future use in hospital settings (Cole et al., 2014).
The pinene-type of essential oil showed moderate antimicrobial activity against Streptococcus pneumoniae, Staphylococcus aureus, Streptococcus agalactiae, Streptococcus pyogenes, Corynebacterium spp. and Campylobacter jejuni with MIC $>50 \%$ (Karapandzova et al., 2015). However, a slight antagonism effect was then observed when ylang-ylang oil was used together with thyme oil against Escherichia coli ATCC 25922, the inhibition zone was reduced by $48.9 \%$ when compared to thyme oil alone (Kon and Rai, 2012). Similarly, another study revealed that blended essential oil preparation which is comprised of lavender, clary sage, and ylang-ylang oils in the ratio 3:4:3 displayed a strong antibacterial and antifungal activities against Staphylococcus aureus ATCC 6538 Staphylococcus epidermidis, Escherichia coli ATCC 25923, Pseudomonas aeruginosa ATCC 9027, and Candida albicans ATCC 10231 (Tadtong et al., 2012).

Table 2 Antimicrobial activity of five essential oils against bacteria isolated from human sperm

\begin{tabular}{|c|c|c|c|c|c|}
\hline & $\begin{array}{c}\text { Citrus } \\
\text { reticulata }\end{array}$ & Citrus paradisi & $\begin{array}{l}\text { Juniperus } \\
\text { communis }\end{array}$ & $\begin{array}{c}\text { Eucalyptus } \\
\text { globulus }\end{array}$ & $\begin{array}{c}\text { Cananga } \\
\text { odorata }\end{array}$ \\
\hline Corynebacterium autimocus & $8.33 \pm 0.58$ & $7.33 \pm 0.58$ & $6.67 \pm 1.15$ & $7.67 \pm 0.58$ & $11.33 \pm 1.15$ \\
\hline Corynebacterium glucuromoliticum & $6.67 \pm 1.53$ & $5.33 \pm 0.58$ & $4.33 \pm 0.58$ & $5.67 \pm 0.58$ & $10.33 \pm 0.58$ \\
\hline Corynebacterium glucuromoliticum & $8.67 \pm 1.15$ & $3.33 \pm 0.58$ & $3.67 \pm 0.58$ & $2.67 \pm 0.58$ & $8.33 \pm 0.58$ \\
\hline Corynebacterium glucuromoliticum & $8.33 \pm 0.58$ & $5.33 \pm 0.58$ & $2.33 \pm 0.58$ & $3.33 \pm 0.58$ & $6.67 \pm 1.53$ \\
\hline Corynebacterium glucuromoliticum & $7.33 \pm 0.58$ & $5.33 \pm 0.58$ & $3.67 \pm 0.58$ & $4.33 \pm 0.58$ & $8.33 \pm 0.58$ \\
\hline Corynebacterium singulare & $5.33 \pm 0.58$ & $5.67 \pm 0.58$ & $7.33 \pm 0.58$ & $7.67 \pm 0.58$ & $9.67 \pm 1.53$ \\
\hline Enterococcus faecalis & $5.33 \pm 0.58$ & $7.33 \pm 0.58$ & $4.67 \pm 0.58$ & $7.67 \pm 0.58$ & $8.67 \pm 0.58$ \\
\hline Enterococcus faecalis & $5.67 \pm 0.58$ & $3.67 \pm 0.58$ & $5.67 \pm 0.58$ & $3.67 \pm 0.58$ & $5.67 \pm 0.58$ \\
\hline Escherichia coli & $5.33 \pm 0.58$ & $6.67 \pm 0.58$ & $8.00 \pm 1.00$ & $9.33 \pm 1.53$ & $11.00 \pm 1.73$ \\
\hline Pantotea aglomerans & $11.00 \pm 1.00$ & $8.33 \pm 0.58$ & $6.67 \pm 0.58$ & $5.67 \pm 0.58$ & $14.33 \pm 1.15$ \\
\hline Pantotea fulva & $5.67 \pm 0.58$ & $2.67 \pm 0.58$ & $3.67 \pm 0.58$ & $11.33 \pm 1.15$ & $10.67 \pm 0.58$ \\
\hline Streptococcus agalactiae & $5.33 \pm 0.58$ & $4.33 \pm 1.53$ & $6.33 \pm 1.15$ & $9.33 \pm 1.53$ & $11.33 \pm 1.15$ \\
\hline Streptococcus agalactiae & $4.33 \pm 0.58$ & $5.33 \pm 0.58$ & $4.67 \pm 0.58$ & $8.33 \pm 0.58$ & $14.33 \pm 0.58$ \\
\hline
\end{tabular}

The antioxidant activity of all five essential oils is shown table 3 . The best antioxidant activity of essential oil was found on Canangaodorata. The antioxidant activity of $C$. odorata extracts was evaluated using DPPH assay to determine the free radical scavenging abilities of the extracts. The result of the study revealed that the ethyl acetate extract of the stem bark of $C$. odorata exhibited the highest percentage of DPPH inhibition (79\%) as compared to other tested plant extracts (Tan et al., 2015). The most important applications of citrus peel essential oils is the presence of some bioactive compounds in them which serve as alternatives to the synthetic antioxidants (Tepe et al., 2006; ViudaMartos et al., 2008; Choi et al., 2000). The antioxidant activity of the oil attributable to electron transfer made juniper berry essential oil a strong antioxidant, whereas the antioxidant activity attributable to hydrogen atom transfer was lower (Höferl $\boldsymbol{e t}$ al., 2014). The Eucalyptus oil extracted from the leaves of Eucalyptus globulus family Myrtaceae was screened for the presence of phytochemicals and their effect on 2, 2-diphenyl-1-picryl-hydrazyl radical (DPPH) and Nitric oxide free radical. Phytochemical screening of the plants showed the presence of flavonoids, terpenoids, saponins and reducing sugars. Eucalyptus globulus is not having any cardiac glycosides and anthraquinones. The free radical scavenging activity of the different concentrations of the leaf oil $(10,20,40,60$ and $80 \%(\mathrm{v} / \mathrm{v})$ in DMSO) of E. globulus increased in a concentration-dependent manner. In DPPH method, the oil in $80 \%(\mathrm{v} / \mathrm{v})$ concentration exhibited $79.55 \pm 0.82 \%$. In nitric oxide radical scavenging assay method, it was found that $80 \%(\mathrm{v} / \mathrm{v})$ concentration exhibited $81.54 \pm 0.94 \%$ inhibition (Mishra et al., 2010).
Table 3 Antioxidant activity of essential oils Essential oil

\begin{tabular}{|lc|}
\hline Citrus reticulata & 3.40 \\
\hline Citrus paradisi & $\mathbf{5 8 . 9 6}$ \\
\hline Juniperus communis & $\mathbf{0 . 1 0 0}$ \\
\hline Eucalyptus globulus & $\mathbf{3 1 . 6 3}$ \\
\hline Cananga odorata & $\mathbf{7 3 . 1 4}$
\end{tabular}

Different kinds of essential oils from various plant material (Citrus paradisi, Citrus reticulata, Juniperus communis, Eucalyptus globulus, and Cananga odorata) were compared by GC-FID chromatography. The most intensive peak in $C$. paradisi essential oil was registered at 15.83 min with area percentage of 87 $\%$ (Fig. 1, red). The analysis of essential oil from $C$. reticulata showed the dominant peak at $15.89 \mathrm{~min}$. (85\% of area percentage) (Fig. 1, green). The major peaks determined for $J$. communis essential oil sample were identified at 10.75 $\min (66.6 \%), 13.24 \mathrm{~min}(16.7 \%)$, and $15.3 \mathrm{~min}(2.9 \%)$ (Fig. 1, blue). Essential oil isolated from E. globulus leafs showed the dominant peak at $17.95 \mathrm{~min}(81.7$ $\%)$ and some minor peaks at $15.5 \mathrm{~min}(7.3 \%)$ and $18.23 \mathrm{~min}(6.4 \%)$ (Fig. 1, pink). The last sample of essential oils was isolated from $C$. odorata flower. The gas chromatograph showed the dominant peaks at $24.38 \mathrm{~min}(22.98 \%), 43.92$ $\min (18.28 \%)$, and $30.42 \mathrm{~min}(7.7 \%)$. Minor peaks were registered at $27.49 \mathrm{~min}$ $(4.6 \%), 29.1 \mathrm{~min}(4.9 \%)$ and $32.79 \mathrm{~min}(3.4 \%)$ (Fig. 1, khaki).

The study revealed that the main components identified from the oxygenated fraction of ylang-ylang essential oil were $p$-methylanisole, methyl benzoate and benzyl benzoate, benzyl acetate, geranyl acetate, cinnamyl acetate and $(E, E)$ - 
farnesyl acetate, linalool, geraniol, and benzyl salicylate (Tan et al., 2015). The chemical composition of the essential oils obtained from the citrus peels, by hydrodistillation, was analyzed by Gas chromatography-mass spectrometry (GC MS). 12 compounds were identified and limonene was the common major component for the three essential oils (77- 97\%) (Boudries et al., 2017). The 80 components identified in the Citrus peel essential oil were all terpenes and related compounds, which comprised of 11 monoterpenes (tota1 $60 \mu \mathrm{g} . \mathrm{g}^{-1}$ of oil), 8 oxygenated monoterpenes $\left(277 \mu \mathrm{g} \cdot \mathrm{g}^{-1}\right), 25$ sesquiterpenes $\left(1.940 \mu \mathrm{g} \cdot \mathrm{g}^{-1}\right), 29$ oxygenated sesquiternpenes $\left(9.420 \mu \mathrm{g} \cdot \mathrm{g}^{-1}\right)$, and 7 esters $\left(175 \mu \cdot \mathrm{g}^{-1}\right)$. The major chemical compounds in the Eucalyptus camaldulensis leaves oil were spathulenol (1.900 $\left.\mu \mathrm{g} . \mathrm{g}^{-1}\right), \alpha$-14-oxymuurolene $\left(1,830 \mu \mathrm{g} . \mathrm{g}^{-1}\right), \beta$-bisabolene $\left(1.190 \mu \mathrm{g} . \mathrm{g}^{-1}\right)$ caryophyllene oxide $\left(1.010 \mu \mathrm{g}_{\mathrm{g}} \mathrm{g}^{-1}\right), \gamma$-patchoulene $\left(848 \mu \mathrm{g} . \mathrm{g}^{-1}\right)$, aristolone $(797$ $\left.\mu \mathrm{g} . \mathrm{g}^{-1}\right), \alpha$-atlantone $\left(561 \mu \mathrm{g} \cdot \mathrm{g}^{-1}\right), \beta$-piotol $\left(332 \mu \mathrm{g} \cdot \mathrm{g}^{-1}\right),(E)$-caryophyllene (328 $\left.\mu \mathrm{g} . \mathrm{g}^{-1}\right)$, and $\beta$-copaen- $4 \alpha$-ol (313 $\mu \mathrm{g}$. $\left.\mathrm{g}^{-1}\right)$ (El-Ghorab et al., 2009). Using GC/FID and GC/MS, 70 compounds were identified in the essential Juniperus communis L. oil (altogether, about $96 \%$ of the volatiles). As main components, the monoterpene hydrocarbons $\alpha$-pinene $(51.4 \%)$, myrcene $(8.3 \%)$, sabinene $(5.8 \%)$, limonene $(5.1 \%)$ and $\beta$-pinene (5.0\%) were found. Concluding, the essential oil mainly comprises mono- and sesquiterpene hydrocarbons $(80.4 \%$ and $9.6 \%$ respectively); oxygenated derivatives are only minor constituents of this essential oil (Höferl et al., 2014).

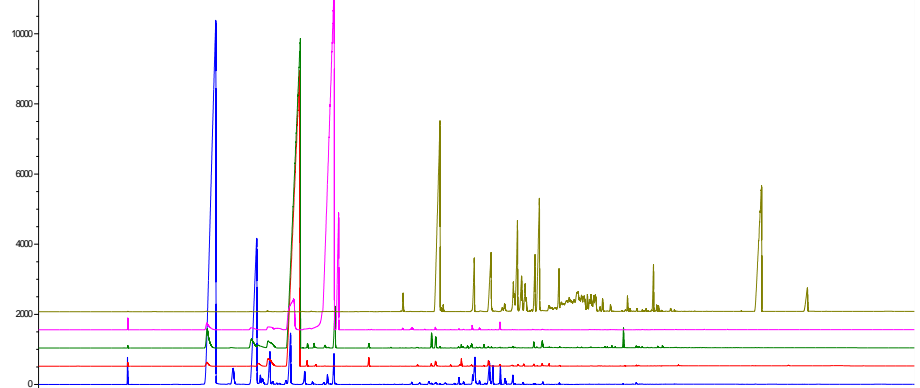

Figure 1 Gas chromatograph for Juniperus communis (blue), Citrus paradisi (red), Citrus reticulata (green), Eucalyptus globulus (pink), and Cananga odorata (khaki) essential oil samples

\section{CONCLUSION}

C. odorata showed the best antioxidant activity when compared with other essential oils. The antimicrobial activity of $C$. odorata has a very good effect against main bacterial species isolated from human semen. The best antimicrobial activity of Cananga odorata essential oil in our study were found against Pantotea aglomerans and Streptococcus agalactiae. Overpopulation is known to be a global issue and public health concern. This activity is probably due the higher level of benzyl benzoate and carryophyllene which were detected in this kind of oils by many authors. Currently, medicinal plants have also received huge attention for its use as contraceptives due to their little side effects. $C$. odorata was also found to possess spermicidal activity in both in vitro and in vivo studies.

Acknowledgments: This study was supported by the Slovak Research and Development Agency under the grant APVV-15-0544.

\section{REFERENCES}

ANITHA, P., INDIRA, M. 2006. Impact of feeding ethanolic extract of root bark of Cananga odorata (Lam) on reproductive functions in male rats. Indian Journal of Experimental Biology. 44(12), 976-980.

BOUDRIES, H., LOUPASSAKI, S., LADJAL ETTOUMI, Y., SOUAGUI, S., BACHIR BEY, M., NABET, N., CHIKHOUNE, A., MADANI, K., CHIBANE, M. 2017. Chemical profile, antimicrobial and antioxidant activities of Citrus reticulata and Citrus clementina (L.) essential oils. International Food Research Journal, 24(4), 1782-1792.

CARPENTER, C.D., O’NEILL, T., PICOT, N., JOHNSON, J.A., ROBICHAUD, G.A., WEBSTER, D., GRAY, C.A. 2012. Anti mycobacterial natural products from the Canadian medicinal plant Juniperus communis. Journal of Ethnopharmacology, 143(2), 695-700. https://doi.org/10.1016/j.jep.2012.07.035 COFFEY, T.J., PULLINGER, G.D., URWIN, R., JOLLEY, K.A., WILSON, S.M., MAIDEN, M.C., LEIGH, J.A. 2006. First insights into the evolution of Streptococcus uberis: a multilocus sequence typing scheme that enables investigation of its population biology. Applied and Environmental Microbiology ,72(2),1420-1428. https://doi.org/10.1128/aem.72.2.1420-1428.2006

COLE, E.R., SANTOS, R.B. DOS, LACERDA JÚNIOR, V., MARTINS, J.D.L., GRECO, S.J., CUNHA NETO, A. 2014. Chemical composition of essential oil from ripe fruit of Schinus terebinthifolius Raddi and evaluation of its activity against wild strains of hospital origin. Brazilian Journal of Microbiology, 45(3), 821-828. https://dx.doi.org/10.1590/S1517-83822014000300009

DELANNOY, C. M., CRUMliSh, M., FONTAINE, M. C., POLlOCK, J. FOSTER, G., DAGLEISH, M. P., TUMBULLI, J.F., ZADOKS, R. N. 2013 Human Streptococcus agalactiae strains in aquatic mammals and fish. BMC microbiology, 13(41), https://doi.org/10.1186/1471-2180-13-41

DIEMER, T., HUWE, P., LUDWIG, M., SCHROEDER-PRINTZEN, I., MICHELMANN, H.W., SCHIEFER, H.G., WEIDNER, W. 2003. Influence of autogenous leucocytes and Escherichia coli on sperm motility parameters in vitro Andrologia 35(2), 100-105 https://doi.org/10.1046/i.14390272.2003.00523.x

EL-GHORAB, A., EL-MASSRY , K.F., ANJUM , F.M., SHAHWARB, M.K., SHIBAMOTO, T. 2009. The Chemical Composition and Antioxidant Activity of Essential Oil of Pakistani Eucalyptus camaldulensis Leaves. Journal of Essentia Oil Bearing Plants, https://doi.org/10.1080/0972060X.2009.10643719

EUCAST, 2019. Clinical breakpoints and dosing of antibiotics. http://www.eucast.org/fileadmin/src/media/PDFs/EUCAST_files/

Breakpoint tables/v 9.0 Breakpoint Tables.pdf

HAHN, W.O., WERTH, B.J., BUTLER-WU, S.M., RAKITA, R.M. 2016. Multidrug-Resistant Corynebacterium striatum Associated with Increased Use of Parenteral Antimicrobial Drugs. Emerging infectious diseases, 22(11), 19081914. https://doi.org/10.3201/eid2211.160141

HÖFERL, M., STOILOVA, I., SCHMIDT, E., WANNER, J., JIROVETZ, L., TRIFONOVA, D., KRASTEV, L., KRASTANOV, A. 2014. Chemical composition and antioxidant properties of juniper berry (Juniperus communis L.) essential oil. Action of the essential oil on the antioxidant protection of Saccharomyces cerevisiae model organism. Antioxidants, 3, 81-98. https://doi.org/10.3390/antiox3010081

CHOI, H.S., H.S. SONG, H. UKEDA AND M. SAWAMURA. 2000. Radicalscavenging activities of citrus essential oils and their components: Detection Using 1,1-Diphenyl-2-picrylhydrazyl. Journal of Agriculture and Food Chemistry, 48(9), 4156-4161. https://doi.org/10.1021/jf000227d

KALITA, A., HU, J., TORRES, A.G. 2014. Recent advances in adherence and invasion of pathogenic Escherichia coli. Current Opinion in Infectious Diseases, 27(5), 459-464. https://doi.org/10.1097/qco.0000000000000092

KARAPANDZOVA, M., STEFKOV, G., CVETKOVIKJ, I., KULEVANOVA,

S., SELA, F. 2015. Chemical composition and antimicrobial activity of essential oils of Juniperus excelsa Bieb. (Cupressaceae) grown in R. Macedonia Pharmacognosy Research, 7(1), 74. https://doi.org/10.4103/0974-8490.147212

KIESSLING, A.A., DESMARAIS, B.M., YIN, H.Z., LOVERDE, J., EYRE, R.C. 2008. Detection and identification of bacterial DNA in semen. Fertility and Sterility, 90, 1744-1756. https://doi.org/10.1016/j.fertnstert.2007.08.083

KON, K., RAI, M. 2012. Antibacterial activity of Thymus vulgaris essential oil alone and in combination with other essential oils. Nusantara Bioscience. 4(2), 50-56. https://doi.org/10.13057/nusbiosci/n040202

LONG, S.S., CHARLES, G., PROBER, M.D., FISCHER, M. 2018. Principles and Practice of Pediatric Infectious Diseases (Fifth Edition), 1688 p. ISBN: 978-0-323-40181-4

MAHFUD, M., PUTRI, D.K.Y., DEWI, I.E.P., KUSUMA, H.S. 2017. Extraction of essential oil from cananga (Cananga odorata) using solvent-free microwave extraction: a preliminary study. Rasayan Journal of Chemistry, 10(1), 86-91, 8691 ISSN 0974-1496. https://doi.org/10.7324/rjc.2017.1011562

MISHRA, A.K., SAHU, N., MISHRA, N., GHOSH, A.K., JHA, S. CHATTOPADHYAY, P. 2010. Phytochemical Screening and Antioxidant Activity of essential oil of Eucalyptus leaf. Pharmacognosy Journal, 2(16), 25 28. https://doi.org/10.1016/S0975-3575(10)80045-8

PURVIS, K., CHRISTIANSEN, E. 1993. Infection in the male reproductive tract. Impact, diagnosis and treatment in relation to male infertility. International Journal of Andrology , 16(1), 1-13. https://doi.org/10.1111/j.1365 2605.1993.tb01146.x

QIANG, H., JIANG, M.S., LIN, J.Y., HE, W.M. 2007. Influence of enterococci on human sperm membrane in vitro. Asian Journal of Andrology, 9(1), 77-81. https://doi.org/10.1111/j.1745-7262.2007.00219.x

SÁNCHÉS-MORENO, C., LARRAURI, A., SAURA-CALIXTO, F. A procedure to measure the antioxidant afficiency of polyphenols. Journal of Science and Food Agriculture, 1998, 76, 270-276.

TADTONG, S., SUPPAWAT, S., TINTAWEE, A., SARAMAS, P. JAREONVONG, S., HONGRATANAWORAKIT, T. 2012. Antimicrobial activity of blended essential oil preparation. Natural Product Communications. 7(10), 1401-1404. https://doi.org/10.1177/1934578x1200701041

TAN, L.T., LEE, L.H., YIN, W.F., CHAN, C.K., ABDUL KADIR, H., CHAN K.G., GOH, B.H. 2015. Traditional Uses, Phytochemistry, and Bioactivities of Cananga odorata (Ylang-Ylang). Evidence-based complementary and alternative medicine, 2015, 1-30. https://doi.org/10.1155/2015/896314

TEPE, B., H.A. AKPULAT, M. SOKMEN, D. DAFERERA, O. YUMRUTAS E. AYDIN, M. POLISSIOU AND A. SOKMEN. 2006. Screening of the antioxidant and antimicrobial properties of the essential oils of Pimpinella anisetum and Pimpinella flabellifolia from Turkey. Food Chemistry, 97(4), 719724. https://doi.org/10.1016/j.foodchem.2005.05.045 
TYAGI, A.K., MALIK, A., 2011. Antimicrobial potential and chemical composition of Eucalyptus globulus oil in liquid and vapour phase against food spoilage microor-ganisms. Food Chemistry, 126(1), 228-235. https://doi.org/10.1016/j.foodchem.2010.11.002

UYSAL, B., SOZMEN, F., AKTAS, O., OKSAL, B.S., KOSE, E.O. 2011. Essential Oil Composition and Antibacterial Activity of the Grapefruit (Citrus paradisi L.) Peel Essential Oils Obtained by Solvent-Free Microwave Extraction: Comparison with Hydrodistillation. International Journal of Food Science \& Technology, 46(7), 1455-1461. https://doi.org/10.1111/j.1365-2621.2011.02640.x VIUDA-MARTOS, M., RUIZ-NAVAJAS, Y., FERNA'NDEZ-LO'PEZ, J PE'REZ-A'LVAREZ, J. 2008. Antifungal activity of lemon (Citrus lemon L.), mandarin (Citrus reticulata L.), grapefruit (Citrus paradisi L.) and orange (Citrus sinensis L.) essential oils. Food Control, 19(12), 1130-1138. https://doi.org/10.1016/j.foodcont.2007.12.003

WENG, S.L., CHIU, C.M., LIN, F.M., HUANG, W.C., LIANG, C., YANG, T. YANG, T.L., LIU, C.Y., WU, W.Y., CHANG, Y.A. CHANG, T.H., HUANG, H.D. 2014. Bacterial communities in semen from men of infertile couples metagenomic sequencing reveals relationships of seminal microbiota to semen quality. PloS one, 9(10), e110152. https://doi.org/10.1371/journal.pone.0110152 